\title{
ANALISA KUANTITATIF PENGARUH PENAMBAHAN KONSTRUKSI SEKAT MELINTANG DAN DOUBLE BOTTOM KAPAL SPOB 3500 DWT TERHADAP LIGHTSHIP
}

\author{
Panut Widodo ${ }^{1^{*}}$ \\ ${ }^{1}$ Program Studi T.Bangunan Kapal, Fakultas Kemaritiman, Universitas Ivet \\ *Email : pntwidodo@gmail.com
}

\begin{abstract}
Abstrak
Pada saat pembaharuan sertifikat class BKI, kapal harus mengikuti dan memenuhi persyaratan peraturan BKI yang terbaru tahun 2019. Kapal SPOB 3500 DWT pengangkut Crude Product Oil (CPO) dan dibangun tahun 1984 ini, harus menambah sekat melintang di tanki muatnya dan merubah konstruksi bottom dari dasar tunggal menjadi dasar ganda (double bottom). Terkait dengan persyaratan peraturan BKI tersebut, maka perlu dilaksanakan perhitungan konstruksi double bottom dan penambahan sekat melintangnya. Dengan penambahan konstruksi sekat melintang dan dasar ganda ini, tentunya akan menambah berat lightship (LWT) kapal. Dalam penelitian ini dilakukan studi terhadap data gambar konstruksi lama yang tersedia, dan perhitungan ukuran konstruksi sekat melintang tambahan dan double bottom berdasarkan rule BKI 2019 Volume II. Dari ukuran dan data konstruksi tersebut dapat dihitung berat konstruksi akibat penambahan sekat dan double bottom dengan metode matematis. Berdasarkan hasil perhitungan maka ada penambahan 2 sekat melintang tebal $8,0 \mathrm{~mm}$ dan inner bottom tebal $8,0 \mathrm{~mm}$, total penambahan berat konstruksi adalah $91032 \mathrm{~kg}$, berat lightship kapal semula 678.84 ton berubah menjadi 768,872 ton, sehingga ada penambahan berat sebesar $13,41 \%$.
\end{abstract}

Kata kunci : Berat, Konstruksi, Kapal, Lightship, dan Perhitungan,

\section{PENDAHULUAN}

Kapal SPOB 3500 DWT ini merupakan kapal jenis tongkang yang memiliki penggerak sendiri dan dibangun pada tahun 1984. Kapal ini dapat dikategorikan dalam jenis kapal oil tanker karena digunakan untuk mengangkut Crude Product Oil (CPO) atau minyak sawit mentah. Perhitungan konstruksi kapal ini, masih menggunakan aturan keselamatan dan Biro Klasifikasi Indonesia (BKI) yang lama, sehingga pada saat pengajuan re-class, kapal ini diwajibkan melaksanakan penyesuaian terhadap aturan keselamatan dan BKI terbaru tahun 2019.

Berdasarkan peraturan BKI tahun 2019 volume II, kapal ini harus menambah sekat melintang pada tanki muatnya dan merubah konstruksi bottomnya dari dasar tunggal (single bottom) menjadi dasar ganda (double bottom. Dengan penambahan konstruksi sekat melintang dan dasar ganda ini, tentunya akan menambah berat kapal dalam kondisi kosong (lightship/LWT.
Terkait dengan hal tersebut, maka perlu dilaksanakan perhitungan ukuran dan berat penambahan konstruksi sekat melintang dan double bottom kapal.

Perhitungan konstruksi kapal pada umumnya akan menghasilkan modulus penampang midship diatas batas minimum. Kelebihan nilai ini berdasarkan peraturan bukanlah suatu masalah. Namun dari segi ekonomi akan dibutuhkan biaya lebih yang sebenarnya dapat dihemat (Rachman dkk, 2018).

Untuk memperjelas arah penulisan ini maka masalah yang akan dibahas adalah perhitungan ukuran konstruksi sekat tambahan dan double bottom, serta penambahan berat konstruksi kapal SPOB 3500 DWT. Sedangkan tujuannya adalah untuk mengetahui :

a) Ukuran konstruksi sekat tambahan dan double bottom yang sesuai aturan BKI 2019 volume II

b) Penambahan berat konstruksinya

c) Prosentase penambahan berat lightship kapal 
Dengan analisa ini diharapkan dapat digunakan sebagai pertimbangan dalam pengambilan langkah untuk tetap menjaga displacement kapal.

\section{LANDASAN TEORI}

Sekat Kapal (Bulkhead)

Sekat dapat dikelompokkan menjadi dua kelompok induk yaitu sekat kedap air (Water tight bulkhead) yang terdiri dari sekat memanjang (longitudinal bulkhead) dan sekat melintang (transverse bulkhead)., dan sekat tidak kedap air (Non water tight bulkhead) yang terdiri dari sekat akomodasi dan wash bulkhead (Mandall, 2017).

Sekat merupakan salah satu konstruksi di kapal yang mempunyai fungsi yaitu sebagai pemisah antara kompartemen atau ruangan di kapal baik pemisah secara melintang maupun memanjang, menambah kekuatan melintang kapal, dan mencegah menjalarnya api saat terjadi kebakaran dan mencegah mengalirnya fluida ke ruangan lain saat terjadi kebocoran. Pemasangan sekat melintang dapat dijumpai pada semua tipe kapal dan menjadi persyaratan Biro Klasifikasi Indonesia (BKI), sedangkan untuk sekat memanjang umumnya hanya dijumpai pada kapal-kapal tertentu saja. Misalnya kapal pengangkut muatan cair dan kapal pengangkut muatan curah. Jika ditinjau dari fungsinya, sekat melintang kapal dapat dibagi menjadi beberapa golongan, yaitu sekat kedap air (watertight bulkhead), sekat kedap minyak, sekat untuk keperluan akomodasi, dan sekat berlubang (swash bulkhead) untuk mengatasi efek permukaan bebas muatan cair (Ikhwan \& Misbah, 2019)

Perbedaan jenis konstruksi sekat melintang yang digunakan yaitu corrugated bulkhead danflat stiffened bulkhead pada kapal mempengaruhi nilai kekuatan kapal dalam mengangkut muatan. Pemilihan jenis konstruksi sekat ini tentunya mempunyai nilai kekuatan yang berbeda. Jenis corrugated memiliki kelebihan yaitu berat konstruksinya ringan dan relatif lebih kuat (Ardianus dkk, 2017). Namun berhubung kekurangan corrugated dalam hal biaya fabrikasinya lebih mahal dan material lebih sulit didapat sehingga akan menyulitkan dalam hal perbaikan maka untuk sekat tambahan dipilih bentuk yang datar (flat stiffened bulkhead).

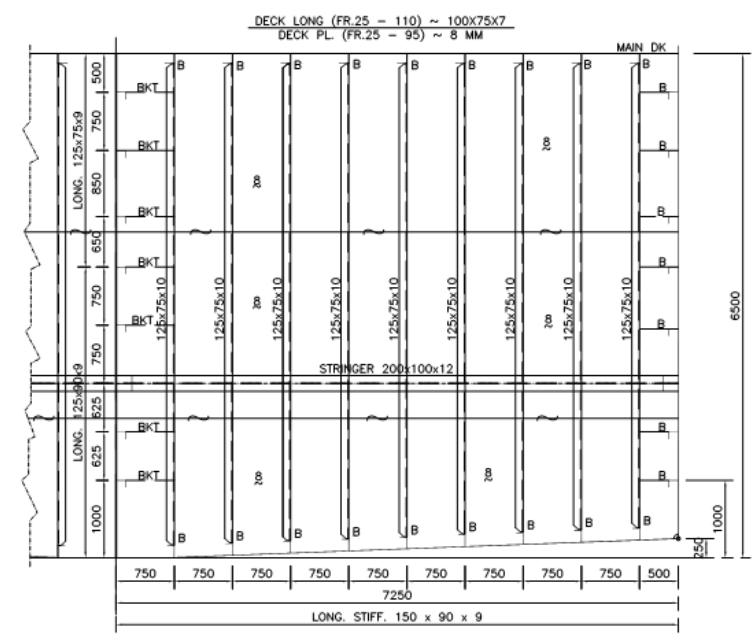

\section{Gambar 1. Konstruksi sekat melintang}

Menurut peraturan BKI tahun 2019 volume II, banyaknya sekat kedap air melintang yang harus dipasang pada kapal bergantung pada panjang maksimun kompartemen kapal (floodable lenght) Panjang tangki muat kapal oil and product tanker yang kurang dari 5000 DWT, tidak boleh lebih besar dari 10 meter diukur pada jarak antar sekat kedap minyak (BKI 2019 Volume II section 24.A.3.4.1). Ukuran ketebalan pelat sekat menurut peraturan BKI 2019 volume II section 11, tebal pelat sekat $\left(t_{s}\right)$ tidak boleh kurang dari :

$$
\begin{array}{ll}
t_{s}=C p \cdot a \cdot \sqrt{p}+t_{k} & (\mathrm{~mm}) \\
t_{\text {min }}=6,0 \cdot \sqrt{f} & (\mathrm{~mm})
\end{array}
$$

\section{Dimana :}

$$
\begin{aligned}
& C p=1,1 \cdot \sqrt{f} \text { (untuk sekat tubrukan) } \\
& C p=0,9 \cdot \sqrt{f} \text { (untuk sekat lainnya) } \\
& \mathrm{a}=\text { jarak penegar sekat (stiffener) } \\
& \mathrm{p}=\text { beban yang diterima sekat } \\
& \mathrm{p}=9,81 \cdot \mathrm{h} \mathrm{KN} / \mathrm{m}^{2} \text { (untuk umum) } \\
& \mathrm{h}=\text { Jarak dari pusat beban sampai } 1,0 \mathrm{~m} \\
& \quad \text { di atas geladak } \\
& \mathrm{h}=1 / 2(\mathrm{H}-\mathrm{hdb})+1,0 \mathrm{~m} \\
& \mathrm{H}=\text { tinggi kapal } \\
& \mathrm{hdb}=\text { tinggi double bottom }
\end{aligned}
$$


$t_{k}=$ Faktor korosi (untuk umum $\left.=1,5\right)$

$f=\frac{235}{R_{e H}}$

$\mathrm{R}_{\mathrm{eH}}=$ kekuatan bahan $\left(\mathrm{N} / \mathrm{mm}^{2}\right)$

$\mathrm{R}_{\mathrm{eH}}=235\left(\mathrm{~N} / \mathrm{mm}^{2}\right)$ untuk $\mathrm{k}=1$ (section 2 point B. 1)

Berdasarkan BKI 2019 volume II section 24.A.12, dalam tangki muat dan ballast di dalam area muatan, ketebalan anggota penguat memanjang, penumpu utama, sekat, dan penegar terkait tidak boleh kurang dari nilai minimum berikut :

$$
t_{\min }=6,5+0,02 \cdot L \quad\left(\mathrm{~cm}^{3}\right)
$$

Dimana :

$\mathrm{L}=\mathrm{Lwl}$, (L tidak boleh lebih besar dari $250 \mathrm{~m}$ )

Modulus penampang penegar sekat dihitung berdasarkan BKI 2019 Volume II Section 11.B.3.1, tidak boleh kurang dari :

$$
W=C s \cdot m \cdot a \cdot l^{2} \cdot p \quad\left(\mathrm{~cm}^{3}\right)
$$

Dimana :

$$
\begin{aligned}
& \text { Cs }=\text { coeffisien stiffener } \\
& C s=0,33 . f \text { (untuk sekat tubrukan) } \\
& C s=0,265 . f \text { (untuk sekat lainnya) } \\
& \begin{array}{l}
\mathrm{a}=\text { jarak penegar sekat (stiffener) } \\
1=\text { panjang yang tidak ditumpu } \\
l=H-h_{d b} \\
\mathrm{~m}=1,0 \\
\mathrm{p}=\text { beban yang diterima sekat }
\end{array}
\end{aligned}
$$

Modulus web stiffener dan stringer sekat melintang pada tangki muat, berdasarkan peraturan BKI 2019 section 3.A.5.3 tidak boleh kurang dari:

$$
W=0,55 \cdot e \cdot l^{2} \cdot p \cdot n_{c} \cdot k\left(\mathrm{~cm}^{3}\right)
$$

Dimana :

$\mathrm{e}=$ jarak stringer atau web stiffener

$\mathrm{n}_{\mathrm{c}}=$ koefisien reduksi tergantung jumlah ikatan silang

$\mathrm{n}_{\mathrm{c}}=0,5$ jika ada satu ikatan silang

$1=$ panjang yang tidak ditumpu

Luas pelat web tidak boleh kurang dari :

$$
A_{w}=0,05 \cdot e \cdot l_{1} \cdot p \cdot k \quad\left(\mathrm{~cm}^{2}\right)
$$

Dimana $1_{1}=1$ dengan mempertimbangkan ikatan silang
Perhitungan modulus plastis dari profil bentuk " $L "$ atau "T" yang sudah direncanakan $\left(Z_{x}\right)$ harus lebih besar dari modulus hasil perhitungan BKI (W). Perhitungan modulusnya adalah :

$Z_{x}=\left(b \cdot t_{f}\right) \cdot\left(h-t_{f}\right)+\frac{t_{w}}{4} \cdot\left(h-2 t_{f}\right)^{2}\left(\mathrm{~cm}^{3}\right)$

Dimana :

$\mathrm{b}=\mathrm{b}_{\mathrm{f}}=$ lebar flange (plat hadap)

$\mathrm{t}_{\mathrm{f}}=$ tebal flange

$\mathrm{h}=\mathrm{h}_{\mathrm{w}}=$ tinggi $w e b$ (plat bilah)

$\mathrm{t}_{\mathrm{w}}=$ tebal web

lebih jelas dapat dilihat pada gambar 2 .

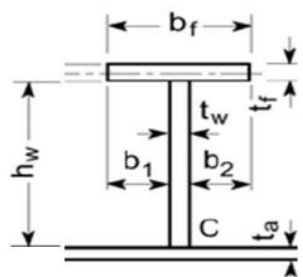

\section{Gambar 2. Profil T}

Perhitungan ukuran bracket menurut BKI 2019 volume II section 3.D.2 adalah :

a. Tebal bracket ( $\left.\mathrm{t}_{\mathrm{br}}\right)$ tidak boleh kurang dari :

$t_{b r}=c \cdot \sqrt[3]{\frac{W}{k 1}}+t_{k} \quad(\mathrm{~mm})$

Dimana :

$\mathrm{c}=1,2$ untuk bracket non-flange

$\mathrm{c}=0,95$ untuk bracket flange

$\mathrm{W}=$ modulus bagian terkecil

$\mathrm{k}_{1}=$ faktor material $=1,0$

$\mathrm{t}_{\mathrm{k}}=$ faktor korosi (umum $=1,5$ )

$\mathrm{t}_{\min }=5,0+\mathrm{t}_{\mathrm{k}}$

b. Panjang lengan bracket $\left(\mathrm{l}_{\mathrm{br}}\right)$ tidak boleh kurang dari :

$$
\begin{aligned}
& l_{b r}=46,2 \cdot \sqrt[3]{\frac{W}{k 1}} \cdot \sqrt{k_{2}} \cdot c_{t}(\mathrm{~mm}) \\
& 1_{\min }=100 \mathrm{~mm} \\
& \text { dimana } \\
& \mathrm{k}_{2}=\text { faktor material }=0,91 \\
& c_{t}=\cdot \sqrt{\frac{t}{t_{a}}} \\
& \mathrm{t}_{\mathrm{a}}=\text { tebal bracket yang dibuat } \\
& \mathrm{t}_{\mathrm{a}} \geq \mathrm{t}
\end{aligned}
$$


Apabila perhitungan tambahan konstruksi sekat melintang dilakukan secara optimal untuk memenuhi persyaratan klassifikasi, maka berat tambahan sekat menjadi minimum, sehingga menurunkan biaya produksi (Ikhwan \& Misbah, 2019).

\section{Dasar Ganda (Double Bottom)}

Konstruksi bottom yang umum digunakan pada kapal dibagi menjadi 2 jenis yaitu dasar tunggal (single bottom) dan dasar ganda (double bottom). Dasar ganda memberikan peningkatan keamanan jika terjadi kerusakan/kebocoran pada bagian bawah, dan juga menyediakan ruang tangki cairan di bagian bawah kapal. Struktur single bottom terdapat pada kapal kecil seperti kapal tunda, ferry, dan kapal kargo dengan berat kurang dari 500 gross tonnage (Eyres, 2006). Menurut SOLAS II1, part B-2.9.1, semua kapal penumpang dan kargo 500 GT atau lebih dan kapal tanker, dasar ganda harus di pasang memanjang dari sekat tubrukan hingga sekat ceruk buritan, sejauh hal ini dapat dilakukan dan kompatibel dengan disain dan kelayakan kerja di kapal (BKI, 2019).

Konstruksi double bottom terdiri dari plat kulit bottom, girder, wrang (floor) dan atau longitudinal frame, plat inner bottom/tank top. Ruang double bottom tidak diperuntukkan untuk muat cargo tetapi digunakan untuk tangki bahan bakar, minyak pelumas, air tawar dan air ballast. Antara tangki minyak dan air tawar harus dibatasi ruangan dengan dua wrang kedap air berjarak satu gading, yang disebut cofferdam

Tinggi double bottom di kapal akan tergantung pada persyaratan klasifikasi yang diikutinya. Pada double bottom kapal yang menggunakan sistem konstruksi gading memanjang, dipasang wrang plat penuh (solid floor) pada setiap jarak gadingnya, Jarak wrang pelat penuh tidak boleh melebihi 3,8 m. Satu buah Side girder dipasang jika lebar kapal melebihi 14 meter dan 2 buah side girder jika lebar melebihi 21 meter (Eyres, 2006).

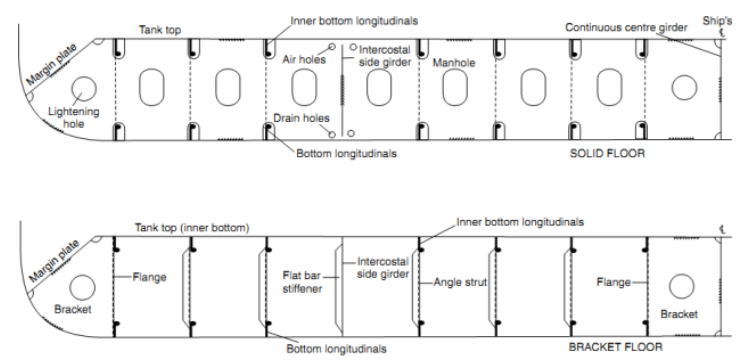

\section{Gambar 3. Konstruksi double bottom sistem gading memanjang}

Menurut peraturan BKI tahun 2019 Volume II section 24.A.3.3.1., Kapal tanker minyak yang kurang dari 5000 DWT harus dipasang double bottom dengan tinggi minimal yang diukur dari garis bottom tertinggi adalah :

$$
\begin{aligned}
& h=\frac{B}{15}(\mathrm{~m}) \text { atau } \\
& \text { hmin }=0,76 \mathrm{~m} \\
& \text { dimana }: \mathrm{B}=\text { Lebar kapal }(\mathrm{m})
\end{aligned}
$$

Jika jarak horizontal antara sisi penumpu tengah (centre girder) dengan lambung melebihi 4,5 $\mathrm{m}$ maka harus dipasang 1 penumpu samping (side girder). (BKI 2019 Volume II section 8.B.3.1).

Perhitungan tebal pelat side girder menurut BKI 2019 volume II section 24.A.12, tebal minimal tidak boleh kurang dari rumus 3 dan section $\mathrm{B}, 3.2$, tidak boleh lebih kecil dari :

$$
t_{s g}=\frac{h^{2}}{120 . h_{a}} \sqrt{k} \quad(\mathrm{~mm})
$$

Dimana :

$$
\begin{aligned}
& \mathrm{h}=350+45 . \mathrm{B}(\mathrm{mm}) \\
& \mathrm{ha}=\text { tinggi side girder yang dibuat }
\end{aligned}
$$

Kapal dengan sistem konstruksi memanjang, jarak wrang penuh (plate floor) tidak boleh lebih dari 5 jarak rata-rata gading pembujur, sedangkan untuk tebal pelat wrang penuh tidak boleh kurang dari :

$$
\begin{aligned}
& t=\left(t_{m}-2,0\right) \cdot \sqrt{k} \quad(\mathrm{~mm}) \\
& t_{\max }=16 \quad(\mathrm{~mm})
\end{aligned}
$$

Dimana :

$$
\mathrm{t}_{\mathrm{m}}=\text { tebal pelat centre girder }
$$


Stiffener wrang alas penuh tidak boleh kurang dari : (BKI 2019 volume II section 8.B.5.4.2)

$$
W=0,55 \cdot a \cdot l^{2} \cdot p \cdot k \quad\left(\mathrm{~cm}^{3}\right)
$$

Dimana :

$$
\begin{aligned}
& \mathrm{p}=\text { beban inner bottom }\left(\mathrm{KN} / \mathrm{m}^{2}\right) \\
& \mathrm{a}=\text { jarak pembujur } \\
& 1=\text { tinggi } \text { wrang }=\mathrm{hdb}
\end{aligned}
$$

Perhitungan tebal pelat inner bottom menurut BKI 2019 volume II section 8.B.4.1. adalah tidak boleh kurang dari :

$$
t=1,1 \cdot a \cdot \sqrt{p \cdot k}+t_{k}(\mathrm{~mm})
$$

Dimana :

$$
\begin{aligned}
& \mathrm{a}=\text { jarak gading/pembujur }(\mathrm{m}) \\
& \mathrm{p}=\text { beban desain }(\mathrm{KN} / \mathrm{m} 2), \text { beban inner } \\
& \quad \text { bottom tergantung dari } \mathrm{p}_{1}, \mathrm{p}_{2} \text { atau } \mathrm{p}_{3} \\
& \mathrm{p}_{1}=10 .\left(\mathrm{T}-\mathrm{h}_{\mathrm{DB}}\right) \\
& \mathrm{T}=\text { tinggi sarat kapal }(\mathrm{m}) \\
& \mathrm{p}_{2}=10 . \mathrm{h}, \text { jika tanki bentuk boundary } \\
& \mathrm{h}= \\
& \quad \text { Jarak dari atas pipa overflow sampai } \\
& \quad \text { inner bottom } \\
& \mathrm{p}_{3}=\mathrm{p}_{\mathrm{i}}=\text { beban muatan }
\end{aligned}
$$

untuk beban muatan $\left(\mathrm{p}_{\mathrm{i}}\right)$ berdasarkan BKI 2019 volume II section 3.C.2 :

$$
p_{i}=9,81 \cdot \frac{G}{V} \cdot h \cdot\left(1+a_{v}\right)\left(\mathrm{KN} / \mathrm{m}^{2}\right)
$$

Dimana :

$\mathrm{G}=$ berat muatan di tangki muat (ton)

$\mathrm{V}=$ volume tangki muat $\left(\mathrm{m}^{3}\right)$

$\mathrm{h}=$ titik tertinggi asumsi tangki terisi penuh

$\mathrm{a}_{\mathrm{v}}=$ faktor percepatan

$a_{v}=0,11 \cdot \frac{v_{0}}{\sqrt{L}} \cdot m$

$\mathrm{m}=1,0$, untuk $0,2<\mathrm{x} / \mathrm{L} \leq 0,7$

$\mathrm{v}_{0}=$ kecepatan kapal, tidak boleh $<\sqrt{L}$

Sedangkan pembujur plat inner bottom, modulusnya tidak boleh lebih kecil dari :

$$
W=n \cdot c \cdot a \cdot l^{2} \cdot p \cdot k \quad\left(\mathrm{~cm}^{3}\right)
$$

Dimana :

$$
\begin{aligned}
& \mathrm{n}=0,44 \text { jika } \mathrm{p}=\mathrm{p}_{2} \\
& \mathrm{n}=0,55 \text { jika } \mathrm{p}=\mathrm{p}_{1} \text { atau } \mathrm{p}_{3} \\
& \mathrm{n}=0,70 \text { jika } \mathrm{p}=\mathrm{p}_{\mathrm{B}} \\
& \mathrm{p}=\text { beban inner bottom }\left(\mathrm{KN} / \mathrm{m}^{2}\right)
\end{aligned}
$$

$\mathrm{c}=0,6$ jika ada penopang pada $1 / 2$

$\mathrm{c}=1,0$ untuk yang lain

$1=$ jarak yang tidak ditumpu $(\mathrm{m})$

\section{Berat Pelat}

Berat pelat merupakan hasil kali volume pelat dengan massa jenisnya, sedangkan volume merupakan hasil kali luasan dengan tebal pelat. Dimana massa jenis baja adalah $7850 \mathrm{~kg} / \mathrm{m}^{3}$

\section{METODE PENELITIAN}

Data-data kapal SPOB 3500 DWT dalam penelitian ini diambil dari studi gambar general arrangement, capacity plan dan construction profile yang didapat dari pemilik kapal. Dari data dilakukan perhitungan ukuran konstruksi penambahan sekat dan double bottom berdasarkan rule BKI 2019 Volume II. Perhitungan berat konstruksi dengan pendekatan matematis.

\section{HASIL DAN PEMBAHASAN \\ Data-data ukuran Kapal}

Data-data SPOB 3500 DWT ini adalah panjang keseluruan $\left(\mathrm{L}_{\mathrm{OA}}\right) 72,52 \mathrm{~m}$; panjang per pendicular (Lpp) 70,20 m; panjang garis air $\left(\mathrm{L}_{\mathrm{WL}}\right) 72,00 \mathrm{~m}$; lebar $(\mathrm{B})$ 14,50 m; tinggi (H) 6,50 m; draft (T) 4,60 m; kecepatan (Vs) 10 knots; koefisien Blok $\left(\mathrm{C}_{\mathrm{b}}\right)$ 0,85; mesin induk ada 2 unit x $800 \mathrm{HP}$ /1000 RPM; sistem konstruksi memanjang; jarak frame $600 \mathrm{~mm}$; jarak web frame 2400 $\mathrm{mm}$, jarak pembujur $750 \mathrm{~mm}$; nomer frame 0 s.d. 117; berat lightship 678.84 ton.

\section{Penentuan tambahan sekat melintang dan tinggi double bottom}

SPOB ini, awalnya memiliki tanki muat/cargo oil tank (COT) berjumlah 6 tanki yang terdiri dari 3 tanki kiri (Portside/P) dan kanan (Starboard/S), nama dan letak nomer frame tangki dapat dilihat pada tabel 1. Dari tabel 1 tersebut dapat diketahui bahwa panjang tanki muat I (P/S) dan tanki muat III(P/S) adalah 30 jarak gading atau sebesar 18 meter, sedangkan panjang tangki muat II (P/S) adalah 14 jarak gading atau sebesar 8,4 meter 
Menurut BKI 2019 Volume II section 24.A.3.4.1, dipersyaratkan bahwa panjang tanki muat kapal oil and product tanker yang kurang dari 5000 DWT, tidak boleh lebih besar dari 10 meter yang diukur pada jarak antar sekat kedap minyak pembatasnya. Sehingga tangki muat I dan III tersebut harus ditambahkan sekat melintang yang diletakkan pada frame nomor (fr.) 40 dan fr. 84. Dengan adanya penambahan sekat melintang ini, maka tangki muat menjadi 5 unit tangki kanan kiri dan panjang tangki muat terbesar adalah 9,0 meter sudah sesuai yang disyaratkan BKI. Jumlah tangki muat dan panjangnya dapat dilihat pada tabel 2 .

Tabel 1. Tanki muat awal

\begin{tabular}{|l|c|c|}
\hline \multicolumn{1}{|c|}{ Nama Tanki } & $\begin{array}{c}\text { Sekat } \\
\text { Melintang } \\
\text { No. Frame }\end{array}$ & $\begin{array}{c}\text { Panjang } \\
\text { Tanki } \\
(\mathbf{m})\end{array}$ \\
\hline Cargo oil Tank I P/S & $69 \sim 99$ & 18.00 \\
Cargo oil Tank II $P / S$ & $55 \sim 69$ & 8.40 \\
Cargo oil Tank III $P / S$ & $25 \sim 55$ & 18.00 \\
\hline
\end{tabular}

Tabel 2. Tanki muat setelah modifikasi

\begin{tabular}{|l|c|c|}
\hline Nama Tanki & $\begin{array}{c}\text { Sekat } \\
\text { Melintang } \\
\text { No. Frame }\end{array}$ & $\begin{array}{c}\text { Panjang } \\
\text { Tanki } \\
\text { (m) }\end{array}$ \\
\hline COT I P/S & $84 \sim 99$ & 9.00 \\
COT II $P / S$ & $69 \sim 84$ & 9.00 \\
COT III $P / S$ & $55 \sim 69$ & 8.40 \\
COT IV P/S & $40 \sim 55$ & 9.00 \\
COT $V P / S$ & $25 \sim 40$ & 9.00 \\
\hline
\end{tabular}

Kemudian berdasarkan peraturan BKI tahun 2019 Volume II section 24.3.3.1. disampaikan bahwa kapal oil tanker yang kurang dari 5000 DWT harus dipasang double bottom dengan tinggi diukur dari garis dasar tertinggi minimal 0,76 meter atau sesuai rumus 7 sebesar $0,97 \mathrm{~m}$.

Berhubung bentuk bottom kapal ini miring dimana tinggi bottom tepi berjarak $250 \mathrm{~mm}$ dari garis dasar (base line), dan tinggi minimal dari bottom tertinggi adalah $0,76 \mathrm{~m}$ maka tinggi double bottom ditentukan setinggi 1010 meter dari base line
Perhitungan tebal pelat sekat melintang tambahan fr. 40 dan fr. 84 sesuai rumus 1 dan 2, dimana :

- $\mathrm{R}_{\mathrm{eH}}=235\left(\mathrm{~N} / \mathrm{mm}^{2}\right)$ untuk $\mathrm{k}=1$

- $f=\frac{235}{R_{e H}}=1$

- $C p=0,9 \cdot \sqrt{f}=0,9$

- $\mathrm{h}=1 / 2(\mathrm{H}-\mathrm{hdb})+1,0=3,745 \mathrm{~m}$

- $p=9,81 . \mathrm{h}=36,74 \mathrm{KN} / \mathrm{m}^{2}$

- $\mathrm{t}_{\mathrm{k}}=1,5$

- $\mathrm{a}=$ jarak stiffener $=0,725 \mathrm{~mm}$

- $\mathrm{L}=72,0 \mathrm{mtr}$

sehingga dari rumus 1, 2 dan 3 didapat:

$$
\begin{aligned}
& t_{s}=\text { Cp.a. } \sqrt{p}+t_{k}=5,5 \mathrm{~mm} \\
& t_{\text {min }}=6,0 \cdot \sqrt{f}=6,0 \mathrm{~mm} \\
& t_{\text {min }}=6,5+0,02 \cdot L=7,94 \mathrm{~mm}
\end{aligned}
$$

Berdasarkan hasil perhitungan di atas dapat dijelaskan bahwa :

1) Untuk konstruksi sekat melintang lama frame 25, 55, 69 dan 99 tebal pelat sekat melintang yang sudah terpasang dikapal adalah $8 \mathrm{~mm}$, sudah memenuhi persyaratan BKI 2019. Jadi untuk konstruksi sekat melintang yang lama tidak perlu diganti.

2) Tebal pelat sekat melintang tambahan fr. 40 dan 84 disamakan dengan yang lama yaitu $8,0 \mathrm{~mm}$

Berdasarkan persamaan 4., dimana panjang tidak ditumpu $(\mathrm{l})=5,49 \mathrm{~m}$, jarak stiffener (a) $=0,725 \mathrm{~m}$ maka modulus stiffener sekat melintang fr. 40 dan 84 adalah :

$W_{s f}=$ Cs.m.a. $l^{2} \cdot p=212,75 \mathrm{~cm}^{3}$

Dari nilai modulus di atas, kemudian dilaksanakan perencanaan profil dan hasil perhitungan modulus dari profil yang direncanakan $\left(Z_{x}\right)$ harus lebih besar dari modulus perhitungan tersebut $\left(\mathrm{W}_{\mathrm{sf}}\right)$.

Berdasarkan nilai $\mathrm{W}_{\text {sf }}$, direncanakan profil "L" ukuran 130x130x12 mm. Dari rumus 6 didapatkan $Z_{x}=217,79 \mathrm{~cm}^{3}$, sehingga profil ukuran ini memenuhi persyaratan $\left(217,79>212,75 \mathrm{~cm}^{3}\right)$.

Modulus web stiffener dapat dihitung berdasarkan rumus 4., dimana jarak web stiffener $(\mathrm{a})=3,625 \mathrm{~m}$ dan $1=5,49 \mathrm{~m}$, maka didapatkan modulus web stiffener $\left(\mathrm{W}_{\mathrm{ws}}\right)=$ $1063,75 \mathrm{~cm}^{3}$. Direncanakan profil "T" ukuran 400x12 + 150x12 mm. 


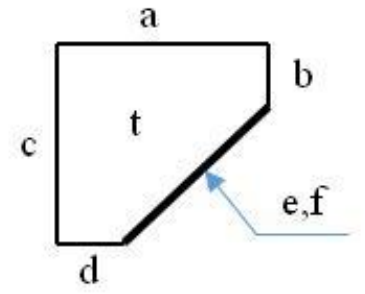

\section{Gambar 5. Dimensi bracket}

Perhitungan bracket menggunakan rumus 8 dan 9, sedangkan modulusnya disesuaikan dengan komponen yang dihubungkan. Penulisan ukuran bracket pada penulisan ini adalah $\mathrm{a} / \mathrm{b} \mathrm{x} \mathrm{c} / \mathrm{d} \times \mathrm{t}+\mathrm{e} \mathrm{x}$ f $x \mathrm{t} \mathrm{mm}$, dimensi lihat gambar 5. Hasil perhitungannya dapat dilihat pada tabel 3 .

\section{Tabel 3. Bracket sekat tambahan}

\begin{tabular}{|c|c|}
\hline Nama & ukuran \\
\hline $\begin{array}{l}\text { Bracket stiffener } \\
\text { (1) }\end{array}$ & $\begin{array}{l}250 / 80 \times 250 / 80 \times \\
10+240 \times 100 \times 10 \\
m m\end{array}$ \\
\hline $\begin{array}{l}\text { Bracket web stiff., } \\
\text { dan stringer (2) }\end{array}$ & $\begin{array}{l}460 / 150 \times 460 / 150 \times \\
12+440 \times 100 \times 12 \\
m m\end{array}$ \\
\hline $\begin{array}{l}\text { Bracket pembujur } \\
\text { sisi/sekat (3) }\end{array}$ & $\begin{array}{l}300 / 100 \times 720 \times 10 \\
\text { mm }\end{array}$ \\
\hline
\end{tabular}

\section{Perhitungan konstruksi double bottom}

.Dengan adanya double bottom ini, maka diperlukan penyesuaian konstruksi bottom yang lama diantaranya adalah :

a. Penambahan plat inner bottom lengkap dengan pembujurnya

b. Penyesuaian ukuran wrang yang semula berbentuk profil $\mathrm{T}$ ukuran $650 \times 300 \times 12$ $\mathrm{mm}$ menjadi pelat setinggi double bottom lengkap dengan stiffener serta lubang peringan agar tidak kedap

c. Side girder yang semula berbentuk profil $\mathrm{T}$ ukuran $650 \times 300 \times 12 \mathrm{~mm}$ menjadi pelat setinggi double bottom dan diberi lubang peringan agar tidak kedap. Ukuran lubang pada side girder tidak boleh melebihi separo tingginya dan setengah jarak gading

Pemilihan beban muatan atau beban inner bottom berdasarkan rumus 10 dan 11, dimana $\mathrm{G}=319,4$ ton, $\mathrm{V}=358,88 \mathrm{~m}^{3}, \mathrm{v}_{0}=$
10 knot, $\mathrm{a}_{\mathrm{v}}=0,13, \mathrm{~h}=5,49 \mathrm{~m}$ maka didapatkan :

$$
\begin{aligned}
& \mathrm{p}_{3}=\mathrm{p}_{\mathrm{i}}=54,16 \mathrm{KN} / \mathrm{m}^{2} \\
& \mathrm{p}_{1}=54,90 \mathrm{KN} / \mathrm{m}^{2}
\end{aligned}
$$

dipilih beban terbesarnya $54,90 \mathrm{KN} / \mathrm{m}^{2}$

Hasil perhitungan konstruksi double bottom berdasarkan rumus 11-16 dan 8,9 dapat dilihat pada tabel 4 .

\section{Tabel 4. Hasil perhitungan konstruksi}

\begin{tabular}{|c|c|c|}
\hline $\begin{array}{c}\text { Nama } \\
\text { konstruksi }\end{array}$ & $\begin{array}{l}\text { tebal } \\
(\mathbf{m m})\end{array}$ & $\begin{array}{c}\text { ukuran } \\
\text { (mm) }\end{array}$ \\
\hline Side girder & 12 & $1010 \times 51000$ \\
\hline Wrang & 10 & $1010 \times 14500$ \\
\hline Stiffener wrang & 6 & $\begin{array}{l}\text { L } 60 \times 60 x \\
1000\end{array}$ \\
\hline $\begin{array}{l}\text { Pelat inner } \\
\text { bottom }\end{array}$ & 8 & $\begin{array}{l}51000 \mathrm{x} \\
14500\end{array}$ \\
\hline $\begin{array}{l}\text { Pembujur inner } \\
\text { bottom }\end{array}$ & 12 & $\begin{array}{l}\text { L } 120 \times 120 \times \\
51000\end{array}$ \\
\hline $\begin{array}{l}\text { Bracket web fr. } \\
\& \text { web stiff. (4) }\end{array}$ & 12 & $\begin{array}{l}625 / 100 x \\
625 / 100\end{array}$ \\
\hline $\begin{array}{l}\text { Bracket stiff, } \\
\text { transv. BHD (1) }\end{array}$ & 10 & $\begin{array}{l}250 / 80 \times \\
250 / 80+ \\
240 \times 100\end{array}$ \\
\hline $\begin{array}{l}\text { Bracket web } \\
\text { stiffener transv. } \\
\text { BHD (2) }\end{array}$ & 10 & $\begin{array}{l}460 / 150 \times \\
460 / 150+ \\
440 \times 100\end{array}$ \\
\hline $\begin{array}{l}\text { Bracket stiff. } \\
\text { wrang (5) }\end{array}$ & 10 & $150 \times 150$ \\
\hline
\end{tabular}
double bottom

Wrang dan side girder ini, dibuatkan lubang peringan dengan ukuran 800 x 600 $\mathrm{mm}$ atau diameter $600 \mathrm{~mm}$.

\section{Berat Penambahan Konstruksi}

Dari data ukuran konstruksi tambahan dan konstruksi kapal SPOB ini maka didapatkan berat seperti pada tabel 5. Berat konstruksi pada tabel 5 ini, harus dikurangi dengan plat lama yang terbuang dan lubang peringan yang ada pada wrang dan side girder. Hasil perhitungan pengurangan berat (dapat dilihat pada tabel 6) sebesar $29968 \mathrm{~kg}$, sehingga total penambahan beratnya sebesar $91032 \mathrm{~kg}$ atau 91,032 ton. 
Tabel 5. Hasil perhitungan berat

\begin{tabular}{|c|c|c|c|c|}
\hline Nama & $\underset{\left(\mathbf{m}^{2}\right)}{\operatorname{Luas}}$ & $\mathbf{t}$ & $\mathbf{n}$ & $\begin{array}{c}\text { berat } \\
\text { (kg) }\end{array}$ \\
\hline Pelat sekat & 92.64 & 8 & 2 & 11635.58 \\
\hline Stiffener & 1.84 & 12 & 32 & 5546.5 \\
\hline Web stiff. & 3.05 & 12 & 4 & 1149.24 \\
\hline Stringer & 8.65 & 12 & 2 & 1629.66 \\
\hline Bracket1 & 0.07 & 10 & 224 & 1230.88 \\
\hline Bracket 2 & 0.24 & 12 & 20 & 452.16 \\
\hline Bracket3 & 0.144 & 10 & 96 & 1085.18 \\
\hline Side girder & 51.51 & 12 & 2 & 9704.48 \\
\hline Wrang & 13.03 & 10 & 15 & 15342.83 \\
\hline Wrang fr.103 & 7.00 & 10 & 1 & 549.5 \\
\hline Wrang fr.107 & 17.16 & 10 & 1 & 1347.06 \\
\hline Stiff. wrang & 0.14 & 7 & 260 & 2000.18 \\
\hline $\begin{array}{l}\text { Pelat inner } \\
\text { bottom (IB) }\end{array}$ & 775 & 8 & 1 & 48668.74 \\
\hline $\begin{array}{l}\text { Pembujur } \\
I B(P I B)\end{array}$ & 11.63 & 12 & 10 & 10955.46 \\
\hline PIB & 12.18 & 12 & 2 & 2294.71 \\
\hline PIB & 11.9 & 12 & 2 & 2241.96 \\
\hline PIB & 11.35 & 12 & 2 & 2138.34 \\
\hline Bracketl & 0.07 & 10 & 220 & 1208.9 \\
\hline Bracket2 & 0.24 & 12 & 5 & 113.04 \\
\hline Bracket4 & 0.27 & 12 & 51 & 1297.13 \\
\hline Bracket5 & 0.01 & 10 & 520 & 408.2 \\
\hline \multicolumn{4}{|c|}{ Total berat konstruksi } & 121000 \\
\hline
\end{tabular}

Tabel 6. Pelat lama yang terbuang

\begin{tabular}{|l|c|c|c|r|}
\hline Nama item & $\begin{array}{c}\text { Luas } \\
\left(\mathbf{m}^{\mathbf{2}} \mathbf{)}\right.\end{array}$ & $\mathbf{t}$ & $\mathbf{n}$ & \multicolumn{1}{c|}{$\begin{array}{c}\text { berat } \\
(\mathbf{k g})\end{array}$} \\
\hline Deck Beam & 8.338 & 12 & 2 & 1570.88 \\
Bracket1 & 0.264 & 10 & 8 & 165.79 \\
Bracket 2 & 0.145 & 10 & 8 & 91.06 \\
Wrang & 12.16 & 12 & 18 & 20623.58 \\
Bracket3 & 0.264 & 10 & 8 & 165.79 \\
Bracket4 & 0.145 & 10 & 70 & 796.78 \\
Web frame & 4.088 & 12 & 4 & 1540.36 \\
Web stiff. & 4.088 & 12 & 2 & 770.18 \\
Pembujur & 11.73 & 8 & 2 & 1473.29 \\
Web frame & 0.27 & 12 & 34 & 864.76 \\
Web stiff. & 0.27 & 12 & 17 & 432.38 \\
Lubang & 0.408 & 10 & 46 & 1473.29 \\
\hline \multicolumn{6}{|c|}{ Total pengurangan berat } & $\mathbf{2 9 9 6 8}$ \\
\hline
\end{tabular}

Berdasarkan hasil perhitungan diatas maka berat lightship kapal semula 678.84 ton akan berubah menjadi 768,872 ton

\section{KESIMPULAN}

Kesimpulan yang dapat diambil dengan adanya penambahan 2 unit sekat melintang pada tangki muat dan penambahan double bottom kapal SPOB 3500 DWT berdasarkan peraturan BKI 2019 volume II ini, adalah sebagai berikut :

a) Ada penambahan 2 sekat tebal 8,0 $\mathrm{mm}$ dan inner bottom tebal $8,0 \mathrm{~mm}$

b) Total penambahan berat konstruksi adalah $91032 \mathrm{~kg}$ atau 91,032 ton

c) Berat lightship kapal semula 678.84 ton berubah menjadi 768,872 ton, ada penambahan berat $13,41 \%$

\section{DAFTAR PUSTAKA}

Ardianus, A., Sujiatanti, S. H., \& Setyawan, D. 2017. Analisa kekuatan konstruksi sekat melintang kapal tanker dengan metode elemen hingga. Jurnal Teknik ITS, 6(2), G183-G188.

Rules, B. K. I. 2019. Rules for Classification and Construction Part 1 Seagoing Ship Volume II: Rules for Hull, Jakarta

Eyres, D. J. 2006. Ship construction. Elsevier.

Ikhwan, A. L., \& Misbah, M. N. 2019. Optimasi Berat Konstruksi Sekat Melintang Kapal dengan Variasi Penegar Sekat. Jurnal Teknik ITS, 8(2), G136G143.

Mandal, N. R. 2017. Ship construction and welding (pp. 170-174). Singapore: Springer.

Rachman, A., Yulianto, T., \& Setyawan, D. 2018. Perancangan Aplikasi Perhitungan dan Optimisasi Konstruksi Profil pada Midship Kapal Berdasar Rule Biro Klasifikasi Indonesia. Jurnal Teknik ITS, 7(1), G12-G18. 